\title{
Estudo de viabilidade técnica e ambiental para utilização de lastro ferroviário degradado em pavimentos
}

O presente artigo apresenta um estudo de viabilidade técnica e ambiental realizado com quatro amostras de lastro ferroviário degradado, obtidas após a operação de desguarnecimento, em uma ferrovia da Região Norte do país. As amostras foram coletadas em quatro pontos diferentes ao longo da ferrovia. 0 objetivo do trabalho é conhecer as propriedades e a composição química do material de lastro degradado considerando a possibilidade de empregá-lo como agregado alternativo em camada de base de pavimentos rodoviários. Para isso, foram realizados ensaios de caracterização física, química, mecânica e classificação ambiental do material de acordo com a NBR 10004. Os resultados encontrados foram satisfatórios, e indicaram se tratar de um material viável para fins de pavimentação rodoviária.

Palavras-chave: Ambiental; Lastro ferroviário; Pavimentação; Agregado alternativo; Base.

\section{Technical and environmental feasibility study for degraded rail ballast use in pavements}

\begin{abstract}
This paper presents a technical and environmental feasibility study carried out with four samples of degraded rail ballast, obtained after the clearance operation, on a railroad in the northern region of the country. Samples were collected at four different points along the railroad. The objective of this work is to know the properties and chemical composition of the degraded ballast material considering the possibility of using it as an alternative aggregate in the base layer of road pavements. For this, tests of physical characterization, chemical, mechanical and environmental classification of the material according to NBR 10004 were performed. The results were satisfactory and indicated that it is a viable material for road paving purposes.
\end{abstract}

Keywords: Environmental; Rail ballast; Paving; Alternative household; Base.

Topic: Desenvolvimento, Sustentabilidade e Meio Ambiente

Reviewed anonymously in the process of blind peer.
Received: 23/06/2019

Approved: 24/07/2019
Bárbara Elis Pereira Silva (iD)

Instituto Militar de Engenharia, Brasil

http://lattes.cnpq.br/8637408381204675

http://orcid.org/0000-0003-0587-6549

barbaraelisps@gmail.com

Antônio Carlos Guimarães (iD)

Instituto Militar de Engenharia, Brasil

http://lattes.cnpq.br/8890983301899546

http://orcid.org/0000-0001-9244-7034

cap-guimaraes@hotmail.com

Ana Carolina da Cruz Reis (iD

Instituto Federal de Minas Gerais, Brasil

http://lattes.cnpq.br/7887791233427589

http://orcid.org/0000-0001-6929-3962

anakkrol@hotmail.com
José Carlos Silva Filho it

Instituto Militar de Engenharia, Brasil

http://lattes.cnpq.br/1347474183362944

http://orcid.org/0000-0001-6413-8605

jose.filho@rumolog.com
Referencing this:

SILVA, B. E. P.; GUIMARÃES, A. C.; REIS, A. C. C.; SILVA FILHO, J. C. S.. Estudo de viabilidade técnica e ambiental para utilização de lastro ferroviário degradado em pavimentos. Revista Ibero-Americana de Ciências Ambientais, v.10, n.4, p.273-288, 2019. DOI: http://doi.org/10.6008/CBPC2179-6858.2019.004.0021

DOI: 10.6008/CBPC2179-6858.2019.004.0021 


\section{INTRODUÇÃO}

A busca por atividades e/ou processos que apresentem viabilidade ambiental, econômica, e que ainda contribuam para o desenvolvimento social, tornou-se frequente em todo o mundo a partir da década de 90, após a conferência conhecida como ECO 92. No encerramento do evento, os países participantes comprometeram-se a buscar formas de progresso socioeconômico sem colocar em risco o meio ambiente. No Brasil, a utilização de rejeitos como agregados alternativos em obras de pavimentação apresentou-se como uma solução viável e bastante útil para destinar certos tipos de materiais que se tornaram inservíveis após um tempo de uso.

Dentro deste contexto, diversas pesquisas começaram a ser desenvolvidas visando o reaproveitamento de materiais que seriam descartados como rejeitos. Retore (2005) avaliou o comportamento mecânico de dois basaltos alterados que são rejeitos da extração de ametista, visando sua aplicação em obras de pavimentação. Na pesquisa de Retore (2005) foram realizados ensaios de abrasão Los Angeles, sanidade a sulfatos, equivalente de areia, lamelaridade, módulo de resiliência e deformações permanentes.

Retore (2005) analisou a durabilidade, deformabilidade e resistência do material e obteve resultados satisfatórios para esses critérios. Desta maneira, os basaltos estudados, rejeitos provenientes da extração de ametista foram recomendados como agregados alternativos em pavimentação de vias de baixo volume de tráfego. Já Amorim (2013) propôs o emprego de resíduos de construção e demolição (RCD) como agregado alternativo de uma mistura solo-agregado para ser empregada em camadas de pavimentos.

No trabalho de Amorim (2013) foi realizada a caracterização física e diversos ensaios visando a análise do comportamento mecânico do material, bem como a construção de um trecho experimental, no qual foi possível analisar seu desempenho funcional, como camada de base. Ao final do trabalho, foi possível concluir que o RCD estudado por Amorim (2013) apresentou viabilidade técnica e econômica e grande potencial para ser empregado como agregado alternativo em obras de pavimentos urbanos.

Diversos trabalhos podem ser citados como exemplo de reaproveitamento de rejeitos oriundos de diferentes processos, como por exemplo Santos (2007), Oliveira (2013), Santos (2013) e Reis (2013). A possibilidade de converter custos gerados pela disposição desses materiais em lucros, agregando valor a eles é de grande interesse para as indústrias.

No que tange à produção de rejeitos, as ferrovias brasileiras produzem anualmente uma grande quantidade desses materiais oriundos da operação de desguarnecimento do lastro ferroviário. Atualmente, a malha ferroviária brasileira de transporte de cargas operada pela iniciativa privada possui $28.614 \mathrm{~km}$. Projetos visando a ampliação, duplicação de linhas e criação de novos pátios para transporte de cargas, de forma a integrá-la aos outros modais, têm sido apresentados como uma medida essencial para o equilíbrio da matriz de transportes brasileira e superação do gargalo logístico que atualmente é enfrentado nesse setor.

O Plano Nacional de Logística e Transportes, com o objetivo de aumentar a eficiência produtiva e buscar um melhor equilíbrio na atual matriz de transportes brasileira, prevê um investimento de $\mathrm{R} \$ 133 \mathrm{bi}$ em 
obras de adequação e expansão de trechos rodoviários e ferroviários no país, sendo que 92 bilhões desse total será unicamente para obras nas vias férreas. Em março do presente ano, foi leiloado um trecho de $1.537 \mathrm{~km}$ pertencentes à Ferrovia Norte-Sul, que reforça a busca por equilíbrio na matriz de transporte de cargas e demonstra investimentos no modal ferroviário.

Esse cenário de crescimento da malha ferroviária associado a uma necessidade de desguarnecimento do lastro degradado mostra uma significativa geração de resíduos que ao invés de ser destinado para aterros sanitários pode ser aproveitado como material alternativo ao agregado convencional em obras de engenharia. $\mathrm{O}$ objetivo deste artigo é avaliar a viabilidade técnica e ambiental do lastro desguarnecido visando seu potencial emprego em camadas de pavimentos.

\section{REVISÃO TEÓRICA}

\section{O Lastro}

O lastro é a primeira camada do pavimento ferroviário. Ele é constituído de material granular e situase entre o sublastro e os dormentes. Selig et al. (1994) caracteriza-o como sendo o seleto material granular britado colocado como o topo da camada de infraestrutura no qual os dormentes são inseridos. Rochas duras tradicionalmente de forma angular, britadas, uniformemente classificadas, livres de poeira e sujeira, e não propensas a cimentar têm sido consideradas bons materiais de lastro. Indraratna (2011) reforça a importância do lastro quando se refere a ele como sendo "um componente-chave da estrutura da via férrea convencional".

Para que apresente um desempenho satisfatório, Brina (1979) cita algumas funções que essa camada deve ser capaz de cumprir, tais como: Resistir a forças verticais, laterais e longitudinais, a fim de manter a via férrea em condições operacionais; Dotar a via férrea de resiliência adequada; Possuir vazios suficientes para alojar possíveis materiais finos de contaminação e permitir a movimentação destas partículas; e Ser dotado de alta capacidade drenante. A figura 1 apresenta os elementos da via permanente e nela é possível identificar o lastro como primeira camada da infraestrutura ferroviária, segundo definição de Selig et al. (1994).

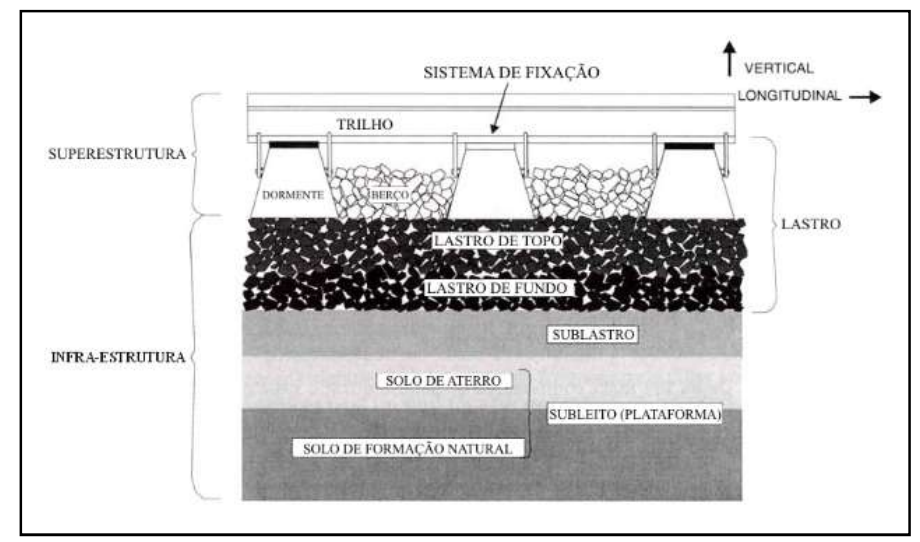

Figura 1: Elementos da via permanente. Fonte: Sousa (2007); Selig et al. (1994).

Com o passar do tempo, a camada de lastro sofre degradação e partículas finas preenchem os vazios existentes entre os grãos, tornando o lastro uma camada mais rígida, dificultando a absorção das tensões 
que continuam sendo impostas pelas cargas. Essa degradação se dá por diferentes fatores. Selig et al. (1994) listam os cinco principais: Quebra do material de lastro: devido à passagem dos veículos, os esforços gerados levam à degradação por abrasão ou ruptura; Bombeamento de finos do subleito: Esse processo acontece quando o material do subleito acende para a camada de lastro em decorrência do efeito das cargas associadas à presença de água no subleito. O material fino aloja-se nos vazios da camada de lastro, alterando a rigidez da estrutura.

Queda de material transportado: Durante o transporte de materiais soltos como minério, carvão, soja uma parte desse material é carregada pelo vento e deposita-se sobre a via; Desgaste de dormentes; e Infiltração proveniente de camadas granulares subjacentes. A operação de socaria, que é um procedimento de manutenção para o nivelamento da via, também contribui para a degradação e quebra das partículas, pois ela se dá por meio da ação vibratória realizada manualmente ou mecanicamente. A ponta destes equipamentos aplica tensões elevadas que levam à quebra e lascam o lastro, gerando partículas finas.

\section{O Desguarnecimento do Lastro}

Quando os vazios são preenchidos por partículas finas, o lastro perde a elasticidade necessária para absorver as tensões impostas pelos veículos rodantes e torna-se rígido. Ademais, o preenchimento dos vazios pelos finos prejudica a permeabilidade, impedindo muitas vezes a drenagem da água da chuva ocasionando formação dos chamados 'bolsões d'água'. Na região onde os bolsões são formados, ocorre a infiltração da água no subleito e perde-se a capacidade de suporte dele, sobrecarregando assim as outras camadas do pavimento ferroviário. Ainda, os bolsões d'água causam deformabilidade na plataforma e instabilidade, aumentando a quebra do material granular.

O processo de desguarnecimento consiste em remover, peneirar e selecionar o material de lastro quando considerado 'degradado' e substituí-lo por partículas de material limpo. A limpeza e a substituição das partículas devolvem à camada de lastro sua capacidade drenante e de absorção de tensões. Para Selig et al. (1994), o processo de desguarnecimento é parte do 'ciclo de manutenção do lastro'. Após a seleção e peneiramento dos grãos do lastro no interior do equipamento, as britas que estão fora da especificação granulométrica e as partículas finas são lançadas na lateral da via e o material retirado durante o desguarnecimento é estocado em pátios até ser destinado a aterros sanitários. Como alternativa ao envio para aterros sanitários, existe a possibilidade de uso do lastro desguarnecido como agregado de base em pavimentos rodoviários, possibilidade a ser estudada neste artigo.

\section{O Pavimento Rodoviário}

Tradicionalmente, os pavimentos rodoviários são classificados em duas categorias. Segundo Medina et al. (2005), são elas: Pavimentos rígidos: Aqueles constituídos por placas de concreto de cimento Portland assente sobre o solo de fundação ou sub-base intermediária; e Pavimentos flexíveis: Constituídos por um revestimento betuminoso sobre uma base granular ou de solo estabilizado granulometricamente.

A principal diferença entre essas duas categorias é a maneira como acontece a distribuição de 
tensões nas camadas subjacentes, devido às diferenças existentes na estrutura deles. Nos pavimentos flexíveis, o revestimento asfáltico funciona basicamente como camada de rolamento e a absorção dos esforços provenientes do tráfego acontece na fundação. Já no pavimento rígido, a placa de concreto utilizada no revestimento possui elevada rigidez em relação às camadas inferiores e, portanto, absorve praticamente todas as tensões provenientes do carregamento aplicado, diminuindo a tensão imposta à fundação. Dessa maneira, a estrutura de cada tipo de pavimento pode ser definida como apresentada na figura 2.

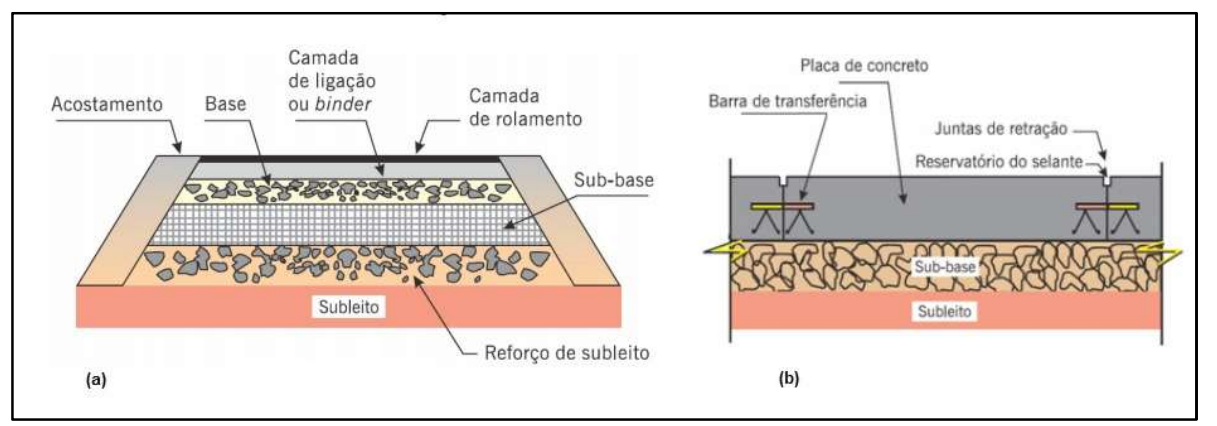

Figura 2: Estrutura dos pavimentos: a) Pavimento Flexível; e b) Pavimento rígido. Fonte: Bernucci et al. (2010)

As bases e sub-bases flexíveis e semirrígidas são classificadas em granulares ou estabilizadas. As granulares, por sua vez, são subdivididas em granulares por estabilização granulométrica ou por macadame hidráulico. Já as estabilizadas, são separadas em 'com cimento, com cal e com betume' e cada vertente possui mais subdivisões. O material utilizado neste estudo apresenta características físicas encontradas em agregados de base. Foram realizados ensaios para verificar seu potencial uso como camada de base estabilizada granulometricamente, onde se tem uma mistura com porcentagens de solo e agregado granular.

\section{Legislação Ambiental Brasileira para Agregados de Obras Rodoviárias}

Atualmente, não existe em vigor no Brasil, uma norma que defina padrões ambientais para aplicação de materiais em obras de pavimentação. Pode-se citar como referência ao assunto o Manual para Atividades Ambientais Rodoviárias, que traz orientações envolvendo a interação entre obras rodoviárias e o meio ambiente.

No referido documento são recomendados métodos e padrões que gerenciem as questões ambientais dos empreendimentos rodoviários, permitindo uma visão ampla à questão ambiental no meio, mostrando problemas existentes, recursos disponíveis e possíveis soluções a serem empregadas. Cita-se, ainda, a norma 70/2006 (DNIT), denominada Condicionantes Ambientais das Áreas de Uso de Obras, que define os procedimentos para o desenvolvimento de atividades relacionadas à execução de obras rodoviárias, de maneira que atenda às condicionantes ambientais nas áreas de uso de obras.

Apesar de explanarem a respeito de obras rodoviárias e meio ambiente, nenhum dos documentos supracitados traz orientações sobre substâncias químicas presentes nos agregados utilizados, que possam viabilizar ou não o uso destes como materiais em pavimentação, seja como material de base, sub-base ou agregado para revestimento asfáltico.

É importante conhecer as propriedades e composições químicas dos agregados, principalmente no 
caso de agregados alternativos provenientes de algum outro processo e que possa ter inserido contaminantes no mesmo. A escória de aciaria é um exemplo de agregado alternativo que teve seu uso normatizado através da Especificação de Serviço no 115/2009 - Pavimentação Rodoviária - Base estabilizada granulometricamente com escória de aciaria - ACERITA.

Nela, os condicionantes ambientais descritos não abordam a questão da composição química da escória, apenas advertem que as exigências e recomendações do órgão ambiental competente devem ser aceitas para que se proceda o licenciamento ambiental do empreendimento. Cita, ainda, que as operações de estocagem e manuseio devem ser realizadas de modo a não permitir que o material atinja cursos d'água.

Percebe-se que as normas existentes específicas para obras de pavimentação, concentram seu foco na descrição dos impactos decorrentes das atividades de construção e nas possíveis medidas mitigadoras relacionadas a esses impactos. Ainda que algumas delas citem que deve haver uma preocupação no estoque e manuseio de agregados alternativos a fim de evitar a contaminação da água, do solo e do ar, nenhuma delas especifica limites aceitáveis para a composição química deles.

Por esse motivo, neste artigo, optou-se por utilizar as normas brasileiras relacionadas à classificação, solubilização e lixiviação de resíduos sólidos de forma geral para o enquadramento do material de lastro. Para classificar o material estudado quanto aos seus potenciais riscos ao meio ambiente e à saúde pública esse trabalho utilizou a NBR 10004, pois o lastro degradado pode ser considerado como resíduo, isto é, um material proveniente de outra atividade e que, não tendo mais utilidade, foi descartado.

Para fins de comparação com a legislação vigente, os valores obtidos nos ensaios de lixiviação e solubilização também foram confrontados com os estabelecidos em algumas resoluções do CONAMA (Conselho Nacional do Meio Ambiente) e na Portaria 2014, do Ministério da Saúde. Essas resoluções, emitidas por órgãos governamentais de controle ambiental, estabelecem valores limites para certas substâncias e definem assim, padrões de lançamento delas no solo, em águas superficiais e subterrâneas. De maneira geral, esses limites são estabelecidos em termos de concentração e desta forma são dependentes das vazões dos corpos d'água. Desta forma, considerou-se ainda esses padrões de lançamento ou emissão definidos por Resoluções CONAMA para o solo e para a água.

\section{MATERIAIS E MÉTODOS}

\section{As amostras de Lastro Degradado}

O material de lastro degradado utilizado neste estudo foi coletado em quatro pontos diferentes de uma estrada de ferro que liga cidades do estado do Pará, na região Norte do país ao Porto de Ponta da Madeira, na cidade de São Luís (MA), localizado na Região Nordeste. Duas dessas amostras foram extraídas no trecho que corta a cidade de Açailândia, porém em quilômetros diferentes, por isso será discriminado como Açailândia 1 e Açailândia 2. Estão assim discriminadas: Amostra 06, extraída do trecho que atravessa a cidade de Parauapebas; Amostra 10, proveniente do trecho que corta a cidade de Marabá; Amostra 23 foi coletada no trecho definido como Açailândia 1 e por fim, Amostra 43 coletada no trecho definido como 
Açailândia 2.

As amostras de lastro foram utilizadas na composição de 6 misturas solo-lastro, considerando 2 tipos distintos de solos, sendo um laterítico arenoso e o outro laterítico argiloso. Utilizou-se como referência para estabilização a Norma DNIT 141/2010 - Pavimentação: Base estabilizada granulometricamente e avaliou-se o comportamento mecânico dessas misturas através do ensaio de módulo resiliente. As figuras de 3 a 6 apresentam as amostras utilizadas neste trabalho. As britas apresentavam granulometria grossa, com o diâmetro máximo de $38 \mathrm{~mm}$. Nota-se que as amostras apresentavam coloração avermelhada, característica dos finos do minério de ferro transportado pela ferrovia e que se depositam no lastro durante o transporte.

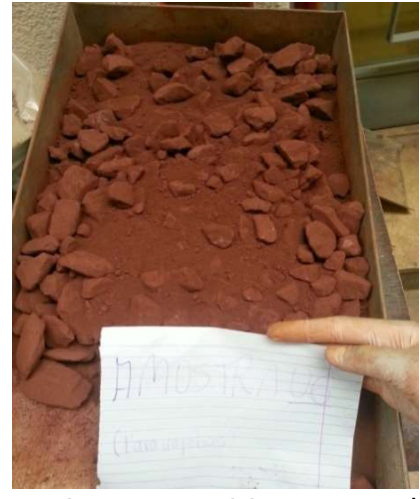

Figura 3: Amostra 06, Parauapebas.

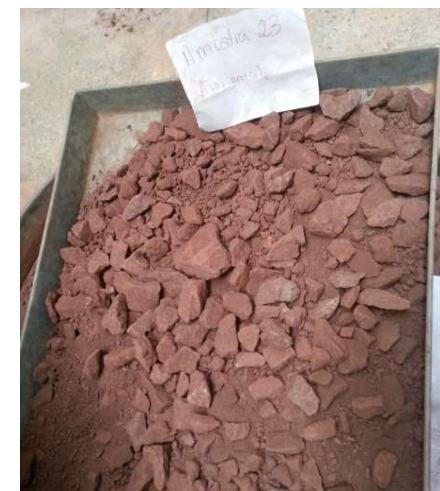

Figura 5: Amostra 23, Açailândia 1.

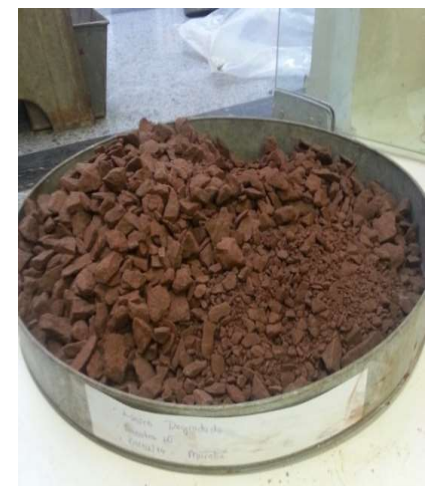

Figura 4: Amostra 10, Marabá.

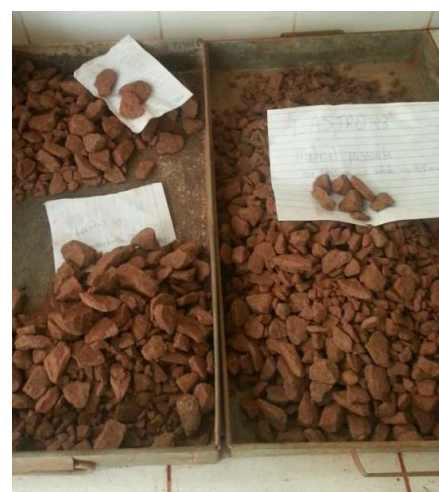

Figura 6: Amostra 43, Açailândia 2.

\section{Os Solos}

Foram utilizados dois tipos de solo para compor a mistura solo-lastro. O primeiro deles é oriundo da cidade de Niquelândia (GO), e sua escolha se deu em função de ser um solo laterítico argiloso de ampla ocorrência no território brasileiro. Este solo foi material de estudo de Silveira (2015). O segundo trata-se de um solo fino avermelhado coletado de um talude de corte na lateral direita (sentido Norte) da ferrovia, na região de Açailândia e que foi pouco trabalhado ao longo do tempo. Foi nomeado 'Amostra 29'. A classificação deles é apresentada na tabela 1.

Tabela 1: Classificação dos Solos.

\begin{tabular}{|c|c|c|c|c|c|c|}
\hline Solos & $\begin{array}{l}\text { Umidade } \\
\text { ótima (\%) }\end{array}$ & $\begin{array}{l}\text { Massa Esp. Aparente Seca } \\
\text { Máxima }\left(\mathrm{g} / \mathrm{cm}^{3}\right)\end{array}$ & $\begin{array}{l}\text { Limite de } \\
\text { Liquidez }\end{array}$ & $\begin{array}{l}\text { Î́ndice de } \\
\text { Plasticidade }\end{array}$ & $\begin{array}{l}\text { Classificação } \\
\text { MCT }\end{array}$ & $\begin{array}{l}\text { Classificação } \\
\text { granulométrica }\end{array}$ \\
\hline $\begin{array}{l}\text { Solo de } \\
\text { Niquelândia }\end{array}$ & $20,60 \%$ & 1,66 & $37,90 \%$ & $19,50 \%$ & LG' & Areia fina siltosa argilosa \\
\hline Solo 29 & $12,70 \%$ & 1,94 & $19,50 \%$ & $10 \%$ & $\mathrm{LA}^{\prime}$ & Areia grossa silto - argiloso \\
\hline
\end{tabular}


Para caracterização ambiental do material estudado, foram realizados ensaios de lixiviação e solubilização, conforme a NBR 10004. Através da análise ambiental é possível enquadrar o lastro degradado em uma das classificações de resíduo sólido previstas na NBR 10004 e identificar os seus constituintes. Conhecendo os constituintes é possível então, compará-los com listagens de resíduos e substâncias cujo impacto à saúde a ao meio ambiente é conhecido.

O material estudado neste artigo passou pelas etapas de lixiviação e solubilização, sendo posteriormente classificado. A lixiviação permite a classificação em: Classe I - Perigos; ou Classe II - Não Perigoso; Já a lixiviação permite a classificação em: Classe IIA - Não inerte; ou Classe IIB - Inerte. A caracterização física do material se deu a partir de ensaios de granulometria, conforme o Método de Ensaio 80/94 (DNER) e Abrasão Los Angeles, conforme o 035/98 (DNER), no Laboratório de Infraestrutura Ferroviária no Instituto Militar de Engenharia.

O ensaio mecânico de determinação da perda ao choque no aparelho Tréton foi realizado conforme a norma 399/99 (DNER) e o de Módulo Resiliente foi realizado de acordo com o procedimento de ensaio descrito em Medina et al. (2005). O ensaio de módulo resiliente foi realizado em um corpo de prova contendo apenas brita do lastro e outros corpos de prova contendo a mistura solo-lastro. A tabela $2 \mathrm{com}$ a quantidade de corpos de prova para cada composição é apresentada a seguir. As figuras 7 e 8 mostram o material durante a confecção do corpo de prova para o ensaio de módulo resiliente. Para a caracterização química foi realizado o ensaio de difratometria de raios-x, para identificar a composição química dos finos presentes no material do lastro.

Tabela 2: Composição dos corpos de prova submetidos ao ensaio de módulo resiliente.

\begin{tabular}{|c|c|c|c|c|}
\hline & Mistura I & Mistura II & Mistura III & Mistura IV \\
\hline Composição & $\begin{array}{c}100 \% \\
\text { Lastro 10 }\end{array}$ & $\begin{array}{c}\text { 80\% Lastro 06 20\% } \\
\text { Solo fino de Niquelândia }\end{array}$ & $\begin{array}{c}\text { 80\% Lastro 23 } \\
\text { Solo fino de Niquelândia }\end{array}$ & $\begin{array}{c}\text { 20\% } \\
\text { 30\% Solo grosso de Açailândia }\end{array}$ \\
\hline $\begin{array}{c}\text { Quantidade } \\
\text { de CPs }\end{array}$ & 1 & 1 & 1 & 4 \\
\hline
\end{tabular}

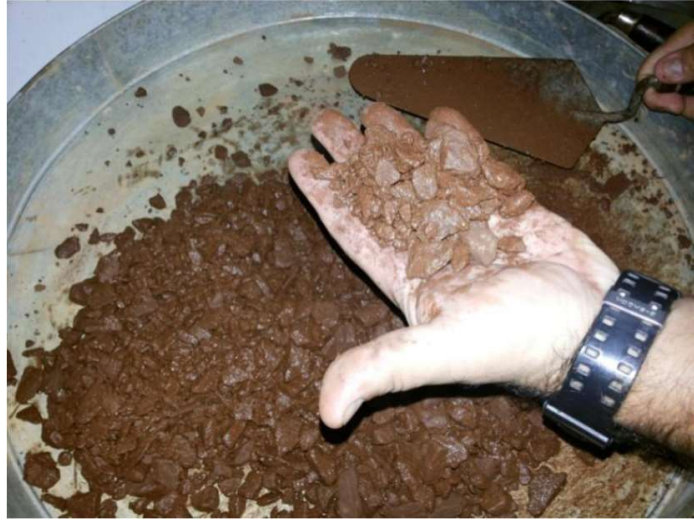

Figura 7: CP da amostra 10 sendo moldado.

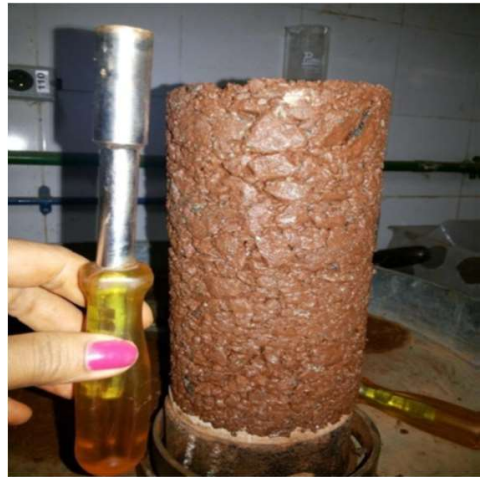

Figura 8: CP da amostra 10 após a retirada do cilindro tripartido.

\section{RESULTADOS E DISCUSSÃO}

\section{Caracterização Ambiental}

Os resultados encontrados nos ensaios de Lixiviação realizados com todas as amostras, não apresentaram valores acima dos prescritos pela NBR 10004. Por isso, o lastro degradado foi classificado como 
resíduo não perigoso, em sua totalidade. Já os ensaios de Solubilização, acusaram para as amostras 10, 06 e 23 a presença de algumas substâncias em concentrações acima daquelas estabelecidas na NBR 10004, sendo, por esse motivo, classificados como resíduos não inertes.

Os materiais recebem essa classificação quando apresentam propriedades de biodegradabilidade, combustibilidade ou solubilidade em água. O material da Amostra 43 não apresentou constituintes solubilizados a concentrações superiores aos padrões de potabilidade de água, e por consequência, foi classificado como resíduo inerte. A tabela 3 apresenta os resultados do ensaio de solubilização obtidos para as amostras. E compara os mesmos com os valores máximos permitidos especificados nas Resoluções 396/08, 357/05, 430/11 e com a Portaria 2914/11.

Tabela 3: Resultados das substâncias encontradas nas amostras 06, 10, 23 e os valores máximos permitidos pela legislação.

\begin{tabular}{|c|c|c|c|c|c|c|c|}
\hline & Parâmetros & $\begin{array}{l}\text { Conc. } \\
\text { Obtida } \\
\text { (mg/L) }\end{array}$ & $\begin{array}{c}\text { *VMP Água } \\
\text { subterrânea para } \\
\text { consumo humano } \\
\text { (mg/L) (Resolução } \\
\text { 396/08) }\end{array}$ & $\begin{array}{l}\text { VMP Água } \\
\text { superficial } \\
\text { Classes I e } \\
\text { Classe II (mg/L) } \\
\text { (Resolução } \\
\text { 357/05) }\end{array}$ & $\begin{array}{l}\text { VMP Água } \\
\text { superficial } \\
\text { Classes III e } \\
\text { Classe IV (mg/L) } \\
\text { (Resolução } \\
\text { 357/05) }\end{array}$ & $\begin{array}{c}\text { VMP Água } \\
\text { superficial após } \\
\text { descarte de } \\
\text { resíduo sólido } \\
\text { (mg/L) (Resolução } \\
\text { 430/11) }\end{array}$ & $\begin{array}{l}\text { VMP Padrão de } \\
\text { potabilidade } \\
\text { (mg/L) } \\
\text { (Resolução } \\
2.914 / 11 \text { ) }\end{array}$ \\
\hline \multirow{4}{*}{ Amostra 06} & Alumínio & 60,03 & 0,2 & 0,1 & 0,2 & 0,2 & 0,2 \\
\hline & Ferro & 00,418 & 0,3 & 0,3 & $\frac{0,3^{1}}{5,0^{2}}$ & 15 & 0,3 \\
\hline & Manganês & 14,007 & 0,1 & 0,1 & 0,5 & 1 & 0,1 \\
\hline & Cianeto Total & 00,26 & 0,07 & 0,005 & 0,022 & 1 & 0,07 \\
\hline \multirow{4}{*}{ Amostra 10} & Alumínio & 00,256 & 0,2 & 0,1 & 0,2 & 0,2 & 0,2 \\
\hline & Fenol & 00,0223 & 0,003 & 0,003 & 0,003 & 0,5 & - \\
\hline & \multirow{2}{*}{ Ferro } & \multirow{2}{*}{10,345} & \multirow{2}{*}{0,3} & \multirow{2}{*}{0,3} & $0,3^{1}$ & \multirow{2}{*}{15} & \multirow{2}{*}{0,3} \\
\hline & & & & & $5,0^{2}$ & & \\
\hline \multirow{3}{*}{ Amostra 23} & Alumínio & 2 & 0,2 & 0,1 & 0,2 & 0,2 & 0,2 \\
\hline & \multirow{2}{*}{ Ferro } & \multirow{2}{*}{0,346} & \multirow{2}{*}{0,3} & \multirow{2}{*}{0,3} & $0,3^{1}$ & \multirow{2}{*}{15} & \multirow{2}{*}{0,3} \\
\hline & & & & & $5,0^{2}$ & & \\
\hline
\end{tabular}

Conforme exposto na tabela 3, na Amostra 06, os elementos Alumínio, Ferro, Manganês e Cianeto estiveram em concentrações superiores às máximas permitidas. No caso do Alumínio e do Manganês, os valores estiveram superiores aos exigidos em todas as resoluções analisadas e na Portaria 2914/11. Já o Ferro e o Cianeto excederam os limites previstos nas resoluções 396 e 357 - para classes I, II e III e na norma de potabilidade.

Assim como na Amostra 06, os elementos Alumínio e Ferro ultrapassaram os limites estabelecidos, na Amostra 10. Considerando o efluente puro, o elemento Alumínio ultrapassaria os limites de lançamento previstos nas três resoluções analisadas e na Portaria 2914/11, que estabelece os padrões de potabilidade da água para consumo humano. O Fenol, por sua vez, apresentou valor acima dos máximos permitidos nas resoluções 396 e 357. Já o elemento Ferro, apresentou concentração superior à permitida nas resoluções 396, 357 - para corpos de água superficial nas classes I, II e III - e pela norma de potabilidade.

Os resultados obtidos para a Amostra 23 indicaram valores acima do limite para os elementos Alumínio e Ferro, sendo o primeiro superior aos limites das 4 normas analisadas e o segundo não apresentou concentração superior àquela estabelecida para a classe de água IV da resolução 357 tampouco para a resolução 430/11. É importante ressaltar que a porcentagem ultrapassada do Fe foi de apenas de 15\%.

Analisando os valores obtidos nos ensaios de solubilização vale destacar que considerando os limites 
de lançamento previstos na Resolução CONAMA 396/08, o lixiviado puro não ultrapassaria os limites estabelecidos para o uso em irrigação ou dessedentação de animais. A respeito dos valores previstos na Resolução no 357/05, não seriam ultrapassados os valores máximos permitidos para a classe IV - águas destinadas à navegação e à harmonia paisagística.

Os limites apresentados na tabela 3 devem ser verificados pela concentração nos corpos d'água após a mistura completa entre o efluente lixiviado e o corpo receptor. Desta forma, quanto maior a vazão do corpo receptor, seja ele subterrâneo ou superficial, menor será a concentração do componente lixiviado no corpo receptor e menos provável será a hipótese de contaminação segundo os limites da legislação no 396/08 voltados para águas subterrâneas e os das Resoluções no 357/08 e 430/11 para águas superficiais.

\section{Caracterização física}

A figura 9 apresenta o resultado do ensaio de granulometria realizado com o material através da curva granulométrica. 0 gráfico exibido na figura 9 permite visualizar com clareza o que foi observado durante o ensaio de granulometria. As linhas tracejadas indicam os limites inferiores e superiores da granulometria da Faixa de projeto A, especificada na norma do DNIT para o projeto de base estabilizada granulometricamente. Fica explícito o enquadramento parcial das amostras 10 e 06, o enquadramento total da Amostra 23 e o não enquadramento da Amostra 43. A amostra 43 apresenta uma quantidade maior de agregados graúdos quando comparada às demais amostras e menor quantidade de material miúdo, por esse motivo não se enquadrou na Faixa $A$, usada como referência para esse estudo.

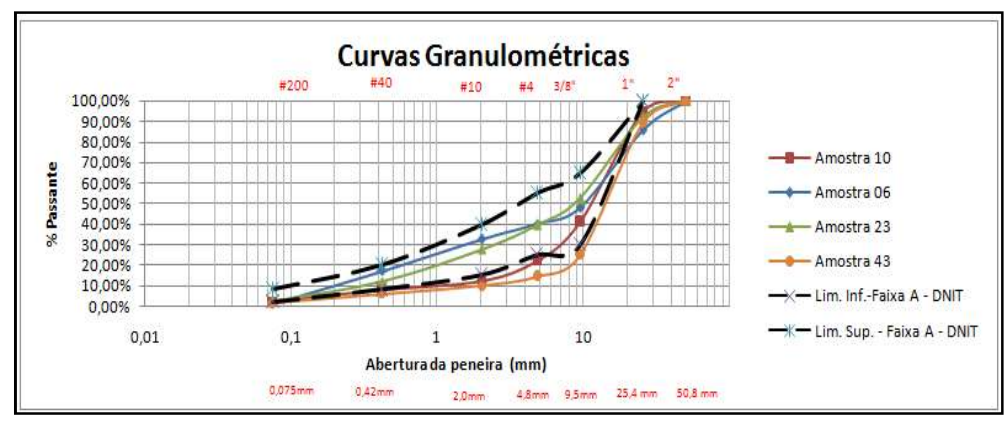

Figura 9: Curvas granulométricas do material de lastro degradado.

Percebe-se também que as amostras 10, 06 e 23 apresentam granulação contínua e são bem graduadas, já a amostra 43 apresenta uma leve granulometria aberta. De acordo com o Manual de Pavimentação do DNER (1996), a granulometria do agregado, revelada na distribuição da curva granulométrica é uma das características que assegura a estabilidade aos pavimentos como resultado do maior atrito interno obtido pelo entrosamento das partículas, desde a partícula mais graúda à mais fina. Outros resultados da caracterização física são apresentados na tabela 4.

Os ensaios para determinação da Densidade foram realizados conforme o método de ensaio 081/98 - Agregados - Determinação da densidade e absorção do agregado graúdo. Os valores obtidos para as densidades real e aparente mostraram-se similares quando comparados aos valores da Brita 1, que é considerada um agregado convencional para obras de pavimentação estudada por Santos (2013). Portanto, 
estão dentro de valores aceitos para o uso desse material como agregado de base.

Tabela 4: Resultados da caracterização física do lastro degradado.

\begin{tabular}{|c|c|c|c|c|c|c|c|}
\hline \multirow[t]{2}{*}{ Parâmetros analisados } & \multicolumn{5}{|c|}{ Resultados encontrados } & \multirow[t]{2}{*}{ Valores -limite } & \multirow[t]{2}{*}{ Referência } \\
\hline & Amostra 10 & Amostra 06 & Amostra 23 & Amostra 43 & Brita 1 & & \\
\hline Densidade real $\left(\mathrm{g} / \mathrm{cm}^{3}\right)$ & 2,72 & 2,61 & 2,66 & 2,79 & 2,73 & - & - \\
\hline Densidade aparente $\left(\mathrm{g} / \mathrm{cm}^{3}\right)$ & 2,74 & 2,88 & 2,74 & 2,81 & 2,67 & - & - \\
\hline Ensaio Tréton & $4,22 \%$ & $12 \%$ & $8,23 \%$ & $4,61 \%$ & $17 \%$ & máx. 60\% & Bernucci et al. (2010) \\
\hline Abrasão Los Angeles & $23,18 \%$ & $35,53 \%$ & $25,93 \%$ & $16,51 \%$ & $23,60 \%$ & máx. 55\% & ES - 141/2010 (DNIT) \\
\hline
\end{tabular}

O ensaio de choque no aparelho Tréton apresentou resultados satisfatórios para o material de lastro. Todos os valores obtidos foram menores do que o valor limite para materiais granulares utilizados em camadas de base, conforme Bernucci et al. (2010), e ainda, menores do que o valor encontrado por Santos (2013) para a Brita 1.

\section{Caracterização química}

Os difratogramas obtidos no ensaio de difração de raios-x para as quatro amostras encontram-se apresentados nas figuras de 10 a 13. Os picos do difratograma representam a ocorrência dos cristais minerais em cada uma delas. A partir deles é possível identificar os elementos ou compostos presentes no material fino analisado.

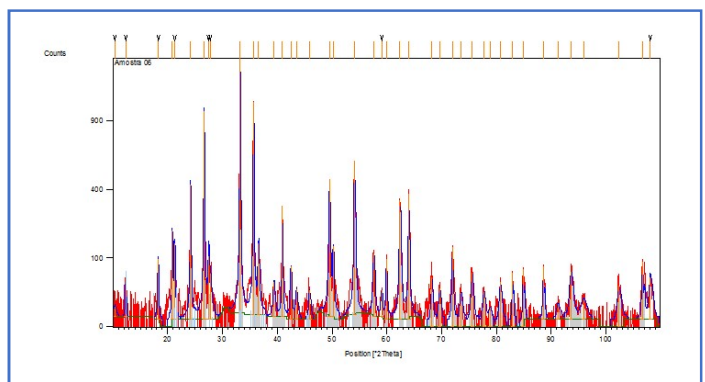

Figura 10: Difratograma da amostra 06.

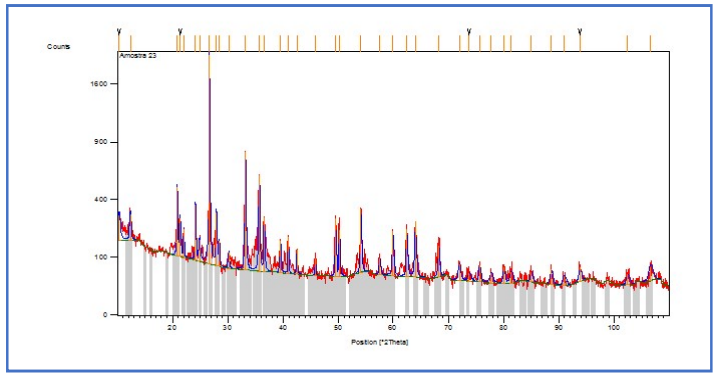

Figura 12: Difratograma da amostra 23.

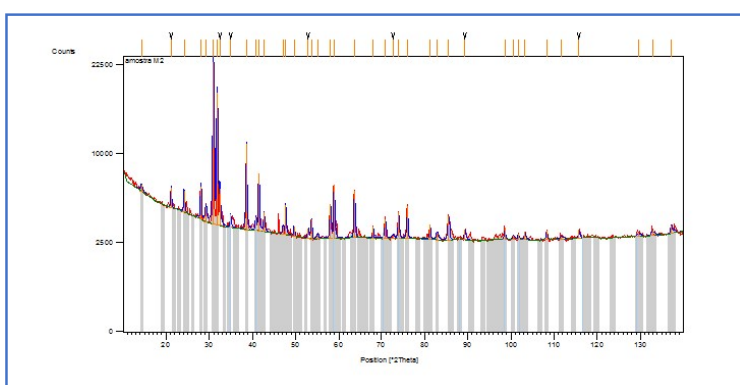

Figura 11: Difratograma da amostra 10.

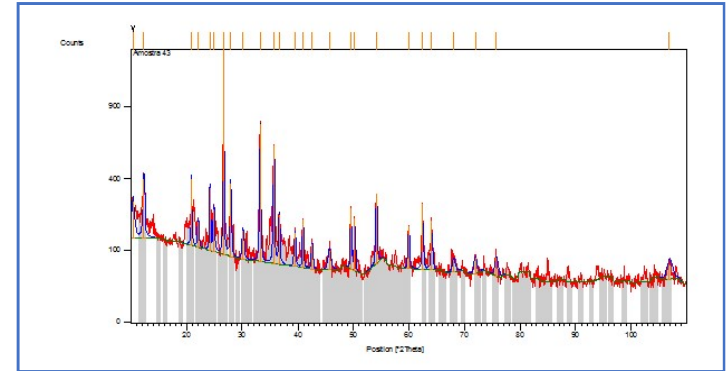

Figura 13: Difratograma da amostra 43.

$\mathrm{Na}$ Amostra 06, foi possível identificar a presença de Quartzo $\left(\mathrm{SiO}_{2}\right)$, Hematita $\left(\mathrm{Fe}_{2} \mathrm{O}_{3}\right)$, e Nitreto de Carbono $\left(\mathrm{C}_{3} \mathrm{~N}_{4}\right)$. Nos finos da amostra 10 os principais constituintes mineralógicos identificados foram a Hematita $\left(\mathrm{Fe}_{2} \mathrm{O}_{3}\right)$, o Quartzo $\left(\mathrm{SiO}_{2}\right)$ e o Óxido de Cálcio e Alumínio $\left(\mathrm{Ca} \mathrm{Al}_{2} \mathrm{O}_{4}\right)$, conhecido como Aluminato de Cálcio. Nos finos da Amostra 23, da região de Açailândia 1 foram identificados Quartzo $\left(\mathrm{SiO}_{2}\right)$, Hematita $\left(\mathrm{Fe}_{2} \mathrm{O}_{3}\right)$ e Óxido de Cálcio e Alumínio $\left(\mathrm{Ca} \mathrm{Al}_{2} \mathrm{O}_{4}\right)$. O difratômetro gerado para a amostra 43 mostrou-se igual ao da Amostra 23, portanto os compostos identificados foram Quartzo $\left(\mathrm{SiO}_{2}\right)$, Hematita $\left(\mathrm{Fe}_{2} \mathrm{O}_{3}\right)$ e Óxido de Cálcio e Alumínio $\left(\mathrm{Ca} \mathrm{Al}_{2} \mathrm{O}_{4}\right)$. 
A análise dos difratogramas, permite afirmar que as fases cristalinas do Quartzo e da Hematita são as mesmas encontradas em todas as quatro amostras. O Dióxido de silício, mais conhecido como sílica $\left(\mathrm{SiO}_{2}\right)$ identificado nas quatro amostras, é o material mais simples à base de silício, quando se considera sua composição química. Existem três formas cristalinas polimórficas principais para a sílica: quartzo, cristobalita e tridimita (CALLISTER, 2000, citado por SILVA, 2015).

O quartzo identificado na porção fina é proveniente da quebra da brita de lastro. Por se tratar de um gnaisse, essa brita apresenta o Dióxido de silício, na forma de quartzo como um dos minerais em sua composição. A Hematita é um mineral que apresenta $70 \%$ de Fe em sua composição, sendo identificado pela fórmula química $\mathrm{Fe}_{2} \mathrm{O}_{3}$. Trata-se de um mineral amplamente distribuído em rochas de todas as idades e forma o minério de Ferro mais abundante e importante (DANA et al., 1970, citado por SILVA, 2015).

A ferrovia da qual foram retiradas as amostras de lastro degradado está ligada ao desenvolvimento e à exploração da Serra dos Carajás. De acordo com Chemale Junior (2013), a Formação de Carajás é composta por diferentes tipologias de minério de ferro e os principais tipos são hematita e jaspilitos. À vista disso, a ocorrência da Hematita nos finos do material amostrado pode ser atribuída à queda do material de minério de ferro transportado nesta ferrovia. Os compostos de Aluminato de Cálcio $\left(\mathrm{Ca} \mathrm{Al}_{2} \mathrm{O}_{4}\right)$ e Nitreto de Carbono $\left(\mathrm{C}_{3} \mathrm{~N}_{4}\right)$ também foram encontrados nas amostras, porém em quantidade pouco significativa. Sua origem é provavelmente de fonte externa e torna-se de difícil identificação uma vez que essa ferrovia também transporta carga geral.

\section{Caracterização mecânica}

O ensaio de módulo resiliente, realizado no equipamento triaxial de cargas repetidas teve o objetivo de conhecer o comportamento elástico dos materiais em função do estado de tensões a que foram submetidos. Dessa maneira é possível avaliar a rigidez, propriedade que exerce grande influência no comportamento estrutural das camadas de um pavimento. A seguir são apresentados os resultados obtidos nos ensaios de módulo de resiliência realizados para o lastro e para as misturas solo-lastro.

O CPM1, composto $100 \%$ de material de lastro degradado da Amostra 10 apresentou valores de módulo de resiliência entre 169MPa e 410MPa e uma deformação plástica total de 1,80mm. A figura 14 apresenta os gráficos obtidos após a aplicação das cargas para a mistura 1 e nota-se que o módulo resiliente mostrou-se dependente da tensão confinante.

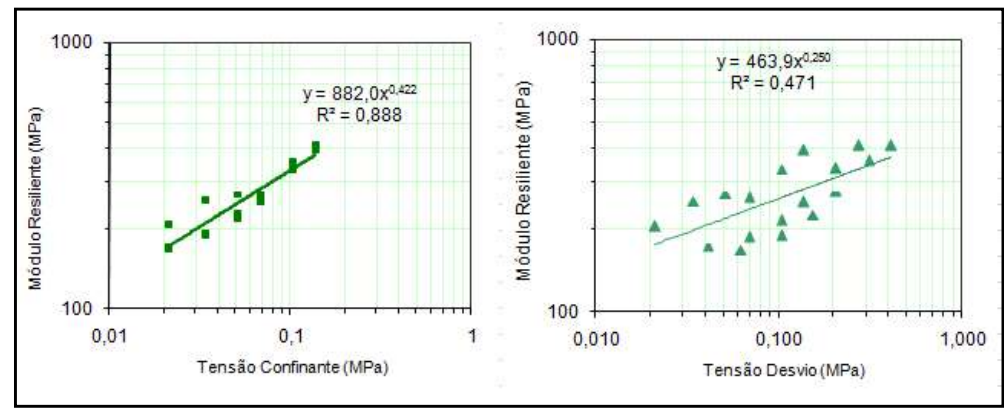

Figura 14: Variação do Módulo Resiliente do CP M1. 
O comportamento dependente da tensão confinante é o esperado para materiais granulares, portanto, era o esperado para este CP que era composto apenas por britas do lastro. O CPM2 referente à mistura II, moldado com $80 \%$ de lastro da Amostra 06 (região de Parauapebas) e 20\% de um solo fino laterítico da cidade de Niquelândia (GO) apresentou valores de MR que variaram de 261MPa a 646MPa e uma deformação plástica total de 1,06mm. A figura 15 apresenta os gráficos obtidos após o a aplicação de cargas.

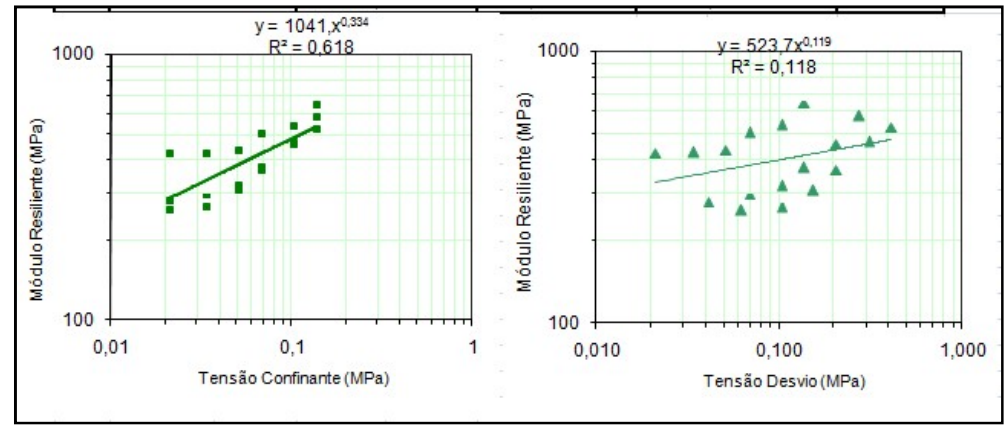

Figura 15: Variação do Módulo Resiliente do CPM2.

Assim como observado no CPM1, o valor de módulo resiliente para o CPM2 variou em função da tensão confinante e apresentou pouca variação em relação à tensão desvio. Atribui-se esse comportamento ao fato de a mistura ser composta, em sua maioria, por agregados granulares graúdos. O CPM3, moldado com $80 \%$ de lastro da Amostra 23 (região de Açailândia 1) e $20 \%$ de solo fino laterítico da cidade de Niquelândia (GO) apresentou valores de MR que variaram de 250MPa a 605MPa e sua deformação plástica total foi a menor de todas as obtidas nos ensaios, sendo de 0,36mm. Os gráficos gerados após o ensaio de módulo resiliente são apresentados na figura 16.

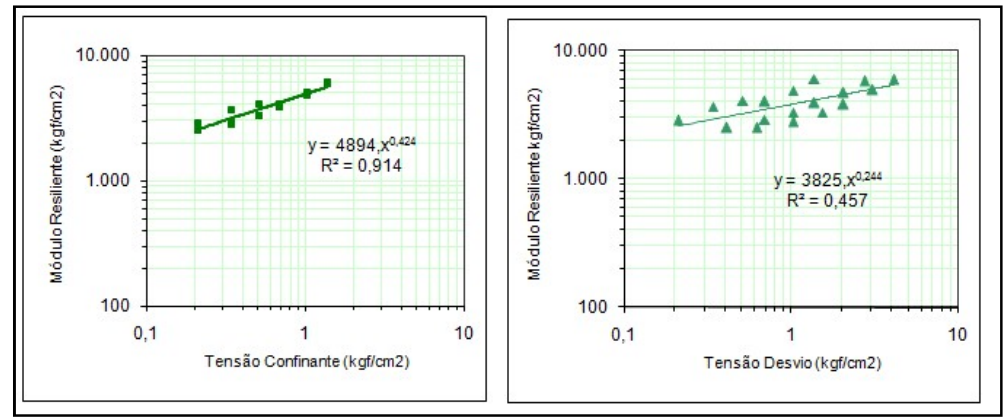

Figura 16: Variação do Módulo Resiliente do CPM3.

Com o material da amostra 43 (Açailândia 2) foram confeccionados 4 corpos de prova de mistura solo - agregado na proporção de $70 \%$ de lastro e $30 \%$ de solo da Amostra 29 , laterítico arenoso da região de Açailândia. O objetivo foi conhecer o comportamento dos CPs quando moldados com diferentes teores de umidade. A tabela 5 apresenta os CPs e o teor de umidade de cada um.

Tabela 5: Teor de umidade dos CPs confeccionados com a mistura 4.

\begin{tabular}{|c|c|c|c|c|}
\hline CP & \multicolumn{1}{|c|}{ CPM4-I M4-II } & CPM4-III & CPM4-IV \\
\hline Teor de umidade & $3,25 \%$ & $4 \%$ & $4,50 \%$ & $5 \%$ \\
\hline
\end{tabular}

Espera-se que os resultados deste ensaio mecânico permitam prever o comportamento da mistura, visando utilizar os dois agregados da mesma região a fim de que sejam reduzidos os custos na execução de 
pavimentos para baixo volume de tráfego nos arredores da cidade. Após os ensaios, observou-se que não foi possível representar o módulo resiliente em função da tensão confinante, como ocorrido para os demais corpos de prova, tampouco em função da tensão desvio. Por esse motivo, optou-se por expressar os valores do módulo resiliente através do modelo composto. O CPM4-I apresentou valores de MR variando de 306MPa a 526MPa e uma deformação plástica total de 3,58mm.

O gráfico obtido para este corpo de prova é apresentado na figura 17. O CPM4-II apresentou valores de MR variando de 235MPa a 705MPa e uma deformação plástica total de 2,89mm. A figura 18 apresenta o gráfico obtido, utilizando o modelo composto. O CPM4-III apresentou valores de MR variando de 280MPa a 590MPa e uma deformação plástica total de 6,45mm, ultrapassando a deformação crítica. A figura 19 apresenta o gráfico 3D do modelo composto obtido a partir dos resultados do ensaio triaxial realizado com o CPM4-III.

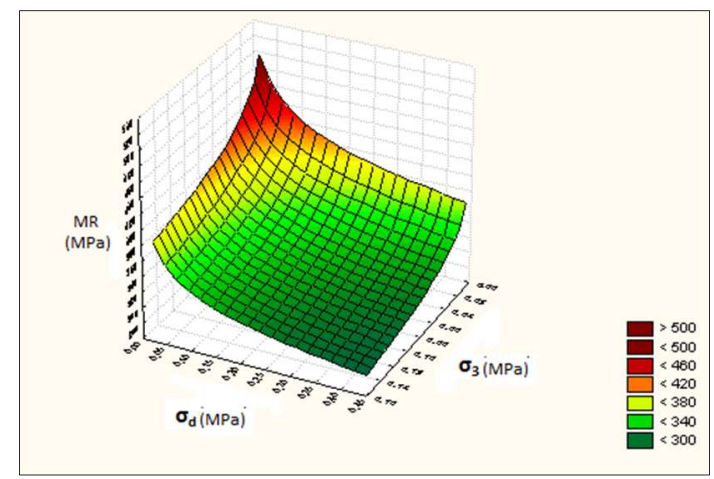

Figura 17: Gráfico 3D do modelo composto do Módulo Resiliente do CPM4-I.

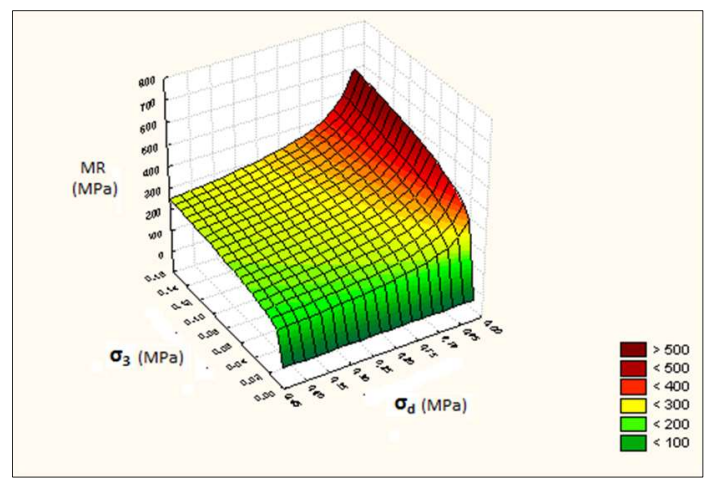

Figura 18: Gráfico 3D do modelo composto do Módulo Resiliente do CPM4-II.

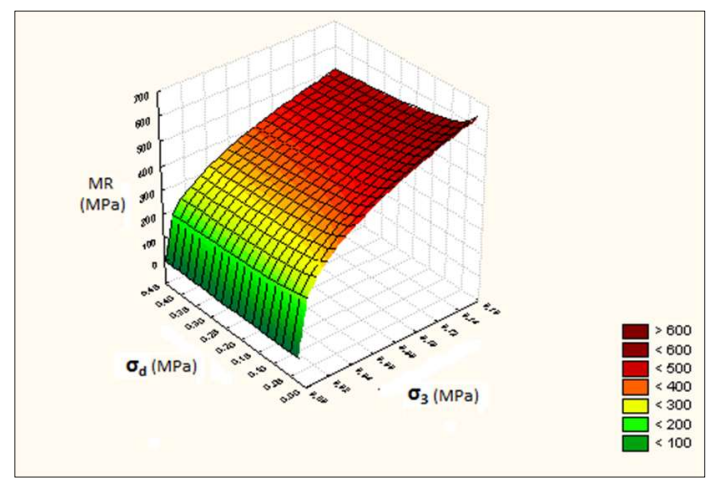

Figura 19: Gráfico 3D do modelo composto do Módulo Resiliente do CPM4-III.

O CPM4-IV apresentou valores de MR variando de 263MPa a 518MPa e uma deformação plástica total de 12,56 mm, maior do que todas as demais. Atribui-se a esse comportamento a umidade elevada deste corpo de prova, que, com $5 \%$ de umidade, mostrou-se pouco resistente e muito deformável. 0 gráfico do modelo composto obtido para o CPM4-IV é apresentado na figura 20. Em todos os casos ensaiados verificouse que as amostras com ou sem adição de solo apresentaram valores de MR superiores a $300 \mathrm{MPa}$, fato que indica que o material estudado apresenta resultados satisfatórios para o uso como agregado em camadas de base de pavimentos rodoviários. 


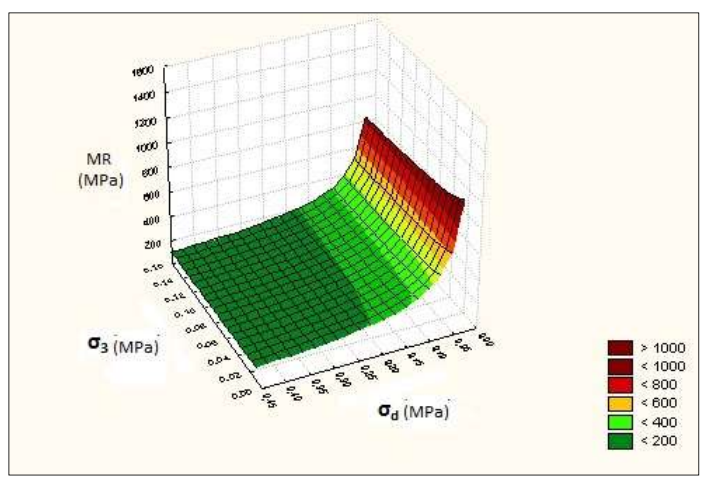

Figura 20: Gráfico 3D do modelo composto do Módulo Resiliente do CPM4-IV.

\section{CONCLUSÕES}

O principal objetivo desta dissertação foi verificar, através de ensaios de caracterização ambiental, física, química e mecânica o potencial emprego do lastro ferroviário degradado como material alternativo em camada de base estabilizada para pavimentação rodoviária. Após a realização dos ensaios conclui-se que a aplicação é viável, visto que o material apresentou resultados satisfatórios aos ensaios realizados.

Os resultados dos ensaios de lixiviação e solubilização caracterizaram as amostras 10, 06 e 23 como não-inertes, uma vez que elementos como Alumínio, Fenol, Ferro, Cianeto Livre e Manganês apresentaramse em concentrações superiores às estabelecidas pela norma NBR 10.004 de classificação de resíduos. Já a Amostra 43 foi classificada como inerte, pois não apresentou características de solubilização, biodegradabilidade nem combustibilidade para nenhum elemento.

Em relação aos valores do lixiviado puro encontrados acima dos limites estabelecidos pelas normas, considerando os efeitos de mistura(s) e autodepuração, geralmente não existirão empecilhos ao uso deste material como agregado em camadas de base. 0 ensaio de Difração de Raios- $\mathrm{x}$ indicou que o material apresenta dois compostos principais em sua composição: $\mathrm{SiO}_{2}$ e $\mathrm{Fe}_{2} \mathrm{O}_{3}$. A presença desses compostos é atribuída à quebra do material de lastro durante sua vida útil e à queda do minério de ferro, abundantemente transportado na ferrovia.

Dos ensaios físicos realizados, foi possível concluir que a granulometria das amostras 10, 06 e 23 mais se aproximaram da Faixa A, especificada pelo DNIT na 141/2010. Os ensaios mecânicos apresentaram resultados satisfatórios para as amostras ensaiadas, já que em todas as misturas os valores de MR foram compatíveis com aqueles obtidos em estudos para materiais a serem empregados em camadas de base.

\section{REFERÊNCIAS}

ABNT. Associação Brasileira de Normas Técnicas. NBR 10004: Resíduos Sólidos: Classificação. Rio de Janeiro: ABNT, 2004.

ABNT. Associação Brasileira de Normas Técnicas. NBR 10005. Procedimento para obtenção de extrato lixiviado de resíduos sólidos. Rio de Janeiro: ABNT, 2004.

ABNT. Associação Brasileira de Normas Técnicas. NBR 10006. Procedimento para obtenção de extrato solubilizado de resíduos sólidos. Rio de Janeiro: ABNT, 2004.
AMORIM, E. F.. Viabilidade Técnica Econômica de Misturas de Solo-RCD em Camadas de Base de Pavimentos Urbanos. Estudo de Caso: Município de Campo Verde (MT). Tese (Doutorado) - Universidade de Brasília, Brasília, 2013.

BERNUCCI, L. L. B.; MOTTA, L. M. G.; CERATTI, J. A. P.; SOARES, J. B.. Pavimentação asfáltica: formação básica para engenheiros. Rio de Janeiro: ABEDA, 2010.

BRINA, H. L.. Estrada de Ferro 1: Via Permanente. Rio de Janeiro: Livro Técnico e Científico S.A., 1979. 
CHEMALE JUNIOR, F.. Minério de Ferro: geologia e geometalurgia. São Paulo: Edgard Blucher, 2013.

CONAMA. Conselho Nacional do Meio Ambiente. Resolução n.357 de 2005. Brasília: CONAMA, 2005.

CONAMA. Conselho Nacional do Meio Ambiente. Resolução n.396 de 2008. Brasília: CONAMA, 2008.

CONAMA. Conselho Nacional do Meio Ambiente. Resolução n.420 de 2009. Brasília: CONAMA, 2009.

CONAMA. Conselho Nacional do Meio Ambiente. Resolução n.430 de 2011. Brasília: CONAMA, 2011.

INDRARATNA, B. S. W. R. C.. Advanced rail Geotechnology Ballasted Track. London: Taylor \& Francis Group, 2011.

OLIVEIRA, R. W. H.. Caracterização da Escória de Ferro Silício-Manganês para a Aplicação como Agregado em Pavimentação Ferroviária. Dissertação (Mestrado) Universidade Federal de Ouro Preto, Ouro Preto, 2013.

REIS, A. C. C.. Propriedades Mecânicas de Misturas Asfálticas Recicladas em Usina Protótipo de Escala Reduzida. Dissertação (Mestrado em Engenharia de Transportes) - Instituto Militar de Engenharia, Rio de Janeiro, 2013.

RETORE, T. S.. Comportamento Mecânico de Agregados de Basaltos Alterados para Pavimentação, Rejeitos de Garimpo de Ametista. Dissertação (Mestrado) Universidade Federal do Rio Grande do Sul, Porto Alegre, 2005.
SANTOS, G. P. P.. Um Estudo Sobre a Utilização da Escória de Ferroníquel em Pavimentação Rodoviária. Dissertação (Mestrado em Engenharia de Transportes) - Instituto Militar de Engenharia, Rio de Janeiro, 2013

SANTOS, M. G. R.. Estudo do Comportamento de Agregado Sintético de Argila Calcinada para Uso em Revestimentos Asfálticos para Manaus. Dissertação (Mestrado) Universidade de Brasília, Brasília, 2007.

SELIG, E. T.; WATERS, J. M.. Track Geotechnology and Substructure Management. London: Thomas Telford, 1994.

SILVA, B. E. P.. Utilização do lastro ferroviário degradado como material de pavimentação. Dissertação (Mestrado) Instituto Militar de Engenharia, Rio de Janeiro, 2015.

SILVEIRA, V. L.. Estabilização de Solos com Cinza de caldeira a Coque para Camadas de Pavimentos. Dissertação (Mestrado em Engenharia de Transportes) - Instituto Militar de Engenharia, Rio de Janeiro, 2015.

SOUSA, G. M.. Estudo Experimental de Escórias de Aciaria Para Fins de Caracterização Tecnológica Como Material de Lastro Ferroviário em Vias Sinalizadas. Dissertação (Mestrado em Geotecnia) - Universidade Federal de Ouro Preto, Ouro Preto, 2007.

WAYHS, C. A. S. P.. Estudo de Materiais Alternativos Utilizados em Pavimentação de Baixo Custo na Região Noroeste do Rio Grande do Sul. Dissertação (Mestrado) Universidade Federal do Rio Grande do Sul, Porto Alegre, 2004.

A CBPC - Companhia Brasileira de Produção Científica (CNPJ: 11.221.422/0001-03) detém os direitos materiais desta publicação. Os direitos referem-se à publicação do trabalho em qualquer parte do mundo, incluindo os direitos às renovaç̃oses, expansões e disseminações da contribuição, bem como outros direitos subsidiários. Todos os trabalhos publicados eletronicamente poderão posteriormente ser publicados em coletâneas impressas sob coordenação da Sustenere Publishing, da Companhia Brasileira de Produção Científica e seus parceiros autorizados. Os (as) autores (as) preservam os direitos autorais, mas não têm permissão para a publicação da contribuição em outro meio, impresso ou digital, em português ou em tradução. 